\title{
Evolución iconográfica y significado del Dios Bes en los templos ptolemaicos ${ }^{1}$
}

\author{
Iconographic Evolution and Meaning of the God Bes \\ in the Ptolemaic Temples
}

\author{
M. a Amparo ArRoyo de la Fuente*
}

\begin{abstract}
RESUMEN
Bes, divinidad arcaica consagrada a la protección del hogar, alcanzó, en época ptolemaica, un auge iconográfico que contrastaría con la escasez de templos propios, ya que su devoción se circunscribía al entorno doméstico y popular. Sus representaciones aparecen en contextos litúrgicos adscritos a otras divinidades, especialmente en los "mammisis" de los grandes templos ptolemaicos, debido a su relación ancestral con la protección de los partos y

los infantes. Estas imágenes tardías relacionan a Bes no sólo con la magia apotropaica y el sentido litúrgico y cultual de la música y la danza, sino también con el concepto de eternidad y, por tanto, con

el complejo mundo funerario egipcio. Dichas representaciones determinarían su posterior difusión iconográfica e iconológica en el ámbito mediterráneo.
\end{abstract}

PALABRAS CLAVE: Ptolemaico - Bes - Iconografía - Música y danza - Magia apotropaica - Ultratumba

\begin{abstract}
Bes, archaic divinity dedicated to the protection of the home, reached, in Ptolemaic epoch, an iconographic summit that would contrast with the shortage of own temples, since his devotion was limited to the domestic and popular environment. His representations appear in liturgical contexts assigned to other divinities, specially in the "mammisis" of the big Ptolemaic temples, due to his ancient relation with the protection of the childbirths and the children. These late images relate Bes not only to the apothropaic magic and the liturgical sense and cultual of the music and the dance, but also to the concept of eternity and, therefore, to the complex funeral Egyptian world. This representations would determine his later iconographic diffusion and iconologic in the Mediterranean area.
\end{abstract}

\section{KEYWORDS:}

Ptolemaic - Bes - Iconography - Music and dance - Apothropaic Magic - Funeral Rites

1 El presente artículo surge a partir de la conferencia impartida el día 15 de marzo de 2006 con el título La Iconografía de Bes en los templos ptolemaicos, como parte del programa del XIII Seminario de Arqueología Clásica, organizado por el Departamento de Ciencias y Técnicas Historiográficas y Arqueología de la Universidad Complutense de Madrid.

* Doctoranda del departamento de Ciencias y Técnicas Historiográficas y Arqueología. Facultad de Geografía e Historia. Universidad Complutense de Madrid. Mail: amparoarroyo@ telefonica.net. 
La compleja iconografía de esta divinidad, sobre cuyo origen se barajan aún diversas teorías ${ }^{2}$, abarca un amplio período cronológico que culminaría en época ptolemaica; por este motivo, el sincretismo de sus representaciones tardías requiere un análisis pormenorizado del origen iconográfico y la evolución iconológica del dios. El desarrollo de la imagen de esta divinidad, que se iría enriqueciendo como síntesis de diferentes entidades divinas, unas con predominio de formas leoninas con origen en las primeras dinastías, otras de aspecto acondroplásico, se complementa con la aportación de nuevos significados procedentes de las veladas implicaciones del dios en relación con el mundo de la magia y del Más Allá. Todo ello culmina en la iconografía habitual del dios en la Baja Época, que estaría destinada a una amplia difusión por todo el Mediterráneo de la mano del comercio fenicio. De hecho, algunas de las formas iconográficas tardías de Bes perduraron en época grecorromana estrechamente vinculadas al culto isiaco.

El propio nombre de Bes sugiere algunas de las principales particularidades del dios. Su expresión es meramente fonética - bs-, y no aporta dato alguno desde el punto de vista semántico ${ }^{3}$, ya que es difícil relacionarlo con términos homófonos que denotan significados referidos a acciones verbales como presentar, iniciar o consumir (Sánchez, A. 2000: 171). No obstante, es sintomática la existencia de un determinativo concreto para la expresión de su nombre (v. glosario). Los determinativos genéricos o semagramas ${ }^{4}$, que carecen de valor fonético, aportan datos gráficos para la comprensión de ciertos vocablos. En este sentido, se puede afirmar que el mayor valor de estos signos de apoyo es iconográfico. Como es habitual en la escritura jeroglífica, los símbolos tienden a la estilización, destacando los elementos esenciales de aquello que se quiere representar o significar. Si bien existe una tipología más estilizada - $34-$, los aspectos iconográficos claves del determinativo del dios Bes, al margen del enanismo y la característica corona de plumas, son dos elementos que lo relacionan directamente con el animal al que se vincula, el león, del que se destaca la melena ventral y la cola, representada de forma muy naturalista, con el mechón o penacho de pelo al final del apéndice del animal.

La estrecha relación de este dios con el león fue una de sus características esenciales que, además, se mantendría a lo largo de toda su evolución. A priori, la imagen representativa de Bes puede resultar anómala en relación con los tópicos iconográficos de la divinidad en el antiguo Egipto, es decir, figuras estilizadas, e idealizadas, dotadas de un acentuado hieratismo. La efigie de este enano, cuyos

2 La indudable relación del dios Bes, tal y como se concibe en época ptolemaica, con divinidades arcaicas como es el caso de Aha - h h- el combatiente, ampliamente representado en los cuchillos mágicos del Reino Medio, sugiere la posibilidad de que el tipo iconográfico fijado en la Baja Época no sea sino una divinidad sincrética cuyo origen habría que buscar en la conjunción de diferentes entidades divinas. Velázquez, F. «Consideraciones...»

${ }^{3}$ Según algunos autores, no obstante, el nombre de $b s$ podría derivar del término $b s 3$, proteger. Lara. F. 1999: 152.

4 «Son gráficos que se colocan, por lo general, después de una secuencia fonética para encuadrar la palabra dentro de un grupo semántico (un mismo determinativo lo podemos encontrar en múltiples palabras) y facilitar la diferenciación de vocablos con homofonía en sus consonantes». SÁNCHEZ, A. 2004: 36. 
rasgos se mimetizan con los del león, difiere de las clásicas representaciones que, bien muestran al animal, bien una figura antropomorfa, o bien ésta última con cabeza zoomorfa 5 . En el caso de Bes, la representación naturalista del animal interfiere con actitudes y rasgos manifiestamente humanos, mientras que las formas antropomorfas mantienen tantos aspectos y elementos animales que, en realidad, encarnan un híbrido. Otras divinidades egipcias, el caso más característico es quizá el de Hathor, denotan también este sincretismo; la diosa nutricia conserva, aún cuando es representada con un bello rostro humano, las orejas de vaca, especialmente en los capiteles hathóricos habituales en época ptolemaica (Fig. 3), elemento éste, las orejas del animal, que también mantiene el dios Bes hasta en sus imágenes más tardías. Es sintomática con respecto a esta tendencia sincrética la importancia que los egipcios concedían a estos apéndices de los dioses, en ocasiones utilizados incluso como amuletos, ya que se consideraba que simbolizaban la facultad del dios de escuchar y, por tanto, atender los ruegos de los suplicantes (Castel, E. 1999: 283-284). Con el objetivo de destacar esta capacidad divina de satisfacer las solicitudes y oraciones de los devotos, cuando el dios era presentado en su condición antropomorfa, se acentuaba la importancia simbólica de este apéndice mostrando su forma animal, que hacía referencia a los cultos zoolátricos más arcaicos.

Las efigies animales de Bes, por otra parte, se apartan del naturalismo habitual. Baste como ejemplo un ungüentario, conservado en el Museo de El Cairo (Carter 579, J.d'E. 62114), en el que una figura del animal aparece erguida alzando una de sus extremidades delanteras y, por tanto, antropomorfizada. Indudablemente, se trata de la representación del animal, sin embargo, tanto su actitud humanizada como los atributos que ostenta, la corona de plumas y el amuleto $s$, así como el gesto de sacar la lengua, lo relacionan con el dios Bes. De hecho, la íntima conexión de este dios con el león ha sugerido la posibilidad de que las características acondroplásicas no sean sino las propias de representar a este animal en postura erguida $^{6}$. No obstante, la relevancia social y simbólica de los enanos en el antiguo Egipto sugiere una estrecha relación de éstos con la divinidad desde las primeras dinastías. El complejo sincretismo iconográfico entre la figura humana y el león, que sí experimenta una tendencia a la antropomorfización tal y como apuntara Jequier (cfr. nota 5) en relación con la religiosidad egipcia, es sin duda fruto de este proceso de desvinculación de cultos zoolátricos; sin embargo, la estrecha relación con el animal no implica la ausencia de otras vinculaciones que hacen referencia al significado más profundo de la divinidad. En este sentido, sus atribuciones son pa-

5 Gustave Jequier ha planteado una teoría, según la cual la religión egipcia habría evolucionado del fetichismo a la zoolatría y, posteriormente, al antropomorfismo, esta última concepción ya consolidada en época tinita (Jequier, G. 1946). En cuanto a Bes, esta evolución no se habría completado, conservando la figura antropomorfa rasgos del inicial culto zoolátrico al león.

6 «Así, las piernas curvadas del dios en el Imperio Medio, que serían atribuibles a la dificultad de mantenerse erguido debido a su naturaleza animal, pudieron haber servido de puente para asumir la nueva iconografía que le conduciría hacia su representación como un enano. Igualmente, la desproporción que las patas traseras de un felino puesto en pie presentan con respecto a la totalidad de su cuerpo, pudo ser asimilada con la que presentan los enanos acondroplásicos.». Velázquez, F. «Consideraciones...» 
ralelas a algunas de las actividades desarrolladas por los enanos en el antiguo Egipto. Las representaciones de enanos, en general, muestran un tipo concreto de malformación, la acondroplasia. Esta alteración se caracteriza por un desarrollo normal del tronco con un acortamiento de las extremidades, brazos y piernas, que, generalmente, va acompañado de una desproporción del cráneo y un tabique nasal aplanado (VV.AA. «La diabetes...»). Son éstas las formas habituales que se perciben en las múltiples imágenes de enanos en el antiguo Egipto y, por tanto, son asimismo las características de la imagen antropomorfa de Bes. Por otra parte, es también frecuente en los acondroplásicos una cierta curvatura de las extremidades inferiores, propia de las imágenes del dios, que parece estar más relacionada con esta malformación que con una posible antropomorfización de la figura erguida del animal.

Se ha apuntado también la posibilidad de un enanismo étnico en las representaciones de Bes, fundamentado en algunos de sus epítetos habituales - Señor del Punt, Señor de Nubia-, que podrían hacer referencia a su origen oriental o centroafricano (Castel, E. 2001: 99-102). Este mismo arquetipo foráneo de la divinidad es el que difundiera Herodoto:

«Con la misma impiedad, Cambises penetró en el santuario de Hephaistos (Ptah) y rió mucho de su estatua. Es preciso decir que esta estatua de Hephaistos es muy parecida a los "patecos" de Fenicia, que los fenicios llevan en sus viajes en la proa de sus trirremes. Para quien no ha visto un "pateco", yo daré esta indicación: es la imagen de un pigmeo» (Herodoto III, 37).

El historiador se refiere aquí a una de las asimilaciones tradicionales de una divinidad egipcia, Ptah, con una griega, Hefesto. Ptah fue el demiurgo de la cosmogonía menfita que, en comparación con el naturalismo de las teologías heliopolitana y hermopolitana, tuvo un carácter marcadamente intelectual. Desde el punto de vista cosmogónico, Ptah-Ta-Tenen, la tierra emergida, es decir, la colina primigenia surgida de las aguas del Caos, es el dios hermafrodita, padre y madre de todos los dioses; Atum, el demiurgo heliopolitano, no es sino una manifestación de Ptah. El aspecto más novedoso de la teología menfita es el relato de la creación: se suponía que Ptah creó el mundo a través del corazón, donde reside el pensamiento - la sabiduría, sỉ - y donde concibe a todos los seres, y de la lengua, el órgano del verbo creador $-h w \mathcal{L}^{7}$. Ptah, precisamente por su carácter de demiurgo hacedor, fue considerado protector de los artesanos, especialmente de los orfebres; sus hijos, denominados patecos, eran representados como enanos y, precisamente, la orfebrería fue una de las ocupaciones tradicionales de aquéllos en el antiguo Egipto ${ }^{8}$. Al margen de la referencia a la difusión y devoción fenicia del culto a Bes, Herodoto define la imagen de culto, probablemente una de estas divinidades menores entendidas como hijos del dios, como pigmeo, lo que implica una interpretación étnica del enanismo en Egipto. Esta presunción está, a su vez, re-

7 Un estudio más amplio en Lopez, J. y Sanmartin, J. 1983: 64-69.

8 Castel, E. 2001: 339-340. Véase el Taller de orfebrería representado en la tumba de Mereruka, en Saqqara (VI Dinastía). 
lacionada con otra actividad para la que se consideraba especialmente dotados a los enanos: la danza. En Egipto se practicaron bailes de origen etíope consagrados al dios itifálico Min, no obstante, estos espectáculos no estuvieron tan sólo vinculados a tradiciones étnicas centroafricanas. Por otro lado, es evidente la estrecha relación de los enanos con la corte, ya desde las primeras dinastías; cabe destacar en este sentido las representaciones halladas en la necrópolis de Gizah, entre las que sobresale la del enano Seneb y su familia ${ }^{9}$, así como los enterramientos de enanos, cercanos a las tumbas de los monarcas tinitas, en el denominado cementerio $B$ de la necrópolis de Abydos (Castel, E. 2004: 11), probablemente, personajes destacados en el contexto del protocolo real.

Esta relación de los enanos con la danza, unida a su estrecha vinculación a la corte, ha llevado a relacionar la actividad de éstos con la que, posteriormente, desarrollarían los bufones en las cortes europeas. Sin embargo, las danzas desempeñadas en Egipto por estos enanos estuvieron más en relación con rituales religiosos, lo que los desvincularía del simple entretenimiento al que se dedicaron los citados bufones. Prueba de la estrecha relación de los enanos con la danza, es la existencia de un término, myw, para designar a los enanos que realizan la danza funeraria ${ }^{10}$, en oposición al utilizado para denominar a los patecos, $n m w$, cuya grafía concluye con un determinativo que representa a un enano desnudo ${ }^{11}$ ( $v$. glosario). Este vínculo de los enanos con las danzas, ya no sólo de cariz religioso sino también funerario, perviviría en los rituales isiacos romanos que se adornaban con cantos y bailes, animados por el sonido de los sistros, tal y como ejemplifican algunas de las pinturas halladas en la ciudad de Herculano y conservadas en el Museo de Nápoles ${ }^{12}$. Estas danzas rituales romanas pudieron tener su origen en las ya citadas en honor de Min o en las múltiples tradiciones que, en este sentido, se desarrollaron en relación con Bes, ya durante la Baja Época. Respecto de la tradición funeraria de la danza en Egipto, señalar que en los Textos de las Pirámides ya se hace referencia a la danza que las almas de Buto, espíritus de antiguos reyes al igual que las almas de Pe y Nejen, llevaban a cabo como manifestación ritual de dolor por la muerte de Osiris ${ }^{13}$. Así pues, es muy probable que los rituales

9 Museo de El Cairo (JE 51280). Quizá la más clara muestra del respeto social del que gozaron los enanos en el antiguo Egipto es esta representación de una familia de la V Dinastía. La destreza del artista para ubicar a los hijos de la pareja por debajo de Seneb, en el espacio que en esta tipología escultórica ocuparían las piernas del esposo, destaca desde el punto de vista compositivo; por otro lado, con respecto a la simbología, resaltan tanto el gesto de cariño de la esposa - no afectada por la enfermedadhacia su marido, como la caracterización del primogénito con la coleta lateral. Este pequeño detalle, propio de la corte, junto con la tipología de representación de la pareja, característica de la aristocracia y similar a la elegida por Rahotep y Nofret, denota la relevancia social de Seneb, que ostentaba, entre otros títulos, los de "Amigo del Rey» y «Director de los enanos encargados del vestuario».

10 Sánchez, A. 2000: 202 (Plural. Tumba Tebana de Antefiqer y su esposa Senet, de Norman y Nina de G. Davies).

11 Sánchez, A. 2000: 239 (Journal of Eguptian Archaelogy 24, 186).

12 En uno de estos frescos, sobre la escalinata del templo y junto a los sacerdotes, impecablemente ataviados con túnicas de lino blanco y con la cabeza rapada, aparecen personajes que agitan los sistros, así como un danzante oculto por una máscara. Museo de Nápoles (Inv. 8919).

13 «iLas almas de Buto bailan por ti; ellos se golpean los cuerpos por ti; golpean sus brazos por ti; ellos despeinan sus cabellos por ti; ellos golpean sus piernas por ti!’». Kaster, J. 1970: 83. 
isiacos diarios desarrollados en Roma no fueran otra cosa que una renovación del drama de la muerte y resurrección de Osiris, en conexión con la costumbre citada en los Textos de las Pirámides y con las danzas ptolemaicas funerarias y rituales en las participaron los myw. Durante la Baja Época es incuestionable la relación de Bes con la danza y la música y, en este sentido, cabe destacar cómo los diferentes aspectos relevantes, desde el punto de vista social, con respecto a los enanos en Egipto determinarían algunas de las más importantes atribuciones de la divinidad. La música tuvo, además, una especial significación en el mito de la Diosa Lejana ${ }^{14}$, en el que participaba activamente Bes. Tanto el ademán de danza como diversos instrumentos musicales formarían parte importante de su propia iconografía y de la de su paredra Beset.

Los puntos en común entre esta divinidad y las actividades desarrolladas por los enanos acondroplásicos no se manifestaron tan sólo en relación con la música y la danza. La principal atribución de Bes como entidad divina, por lo que gozó de una especial devoción en el ámbito cotidiano y entre las clases más humildes de la población, no fue otra que la protección de los partos y, por extensión, tanto de la gestación como del momento de la concepción, así como también de los procesos posteriores al propio alumbramiento, la lactancia y crianza de los más pequeños, convirtiéndose en un auténtico patrón del matrimonio y la familia. En este sentido, es interesante la actividad desempeñada por algunas mujeres acondroplásicas y, en general, por los enanos, como custodios de los recién nacidos. Teniendo en cuenta que el porcentaje de transmisión genética de la acondroplasia alcanza el cincuenta por ciento (VV.AA. «La diabetes...») y que, por la propia constitución física de las mujeres acondroplásicas, sus partos son especialmente difíciles, el índice de supervivencia de sus hijos es muy bajo. Por ello, en Egipto, «el enano que llegara a adulto sería considerado un ser especial que había sobrevivido a los grandes peligros del parto, de aquí que al dar esta apariencia al dios se quisiera reflejar un vínculo directo con su función» (Romano, J.F. 1989: 110-112.). Ésta que fuera su principal labor de protección divina se complementaba ya no tanto con la danza como con la música en general, ya que se consideraba que no sólo lograba amansar a las fieras sino que también podía ahuyentar a los malos espíritus, de modo que era frecuente la iconografía de Bes con diferentes instrumentos musicales, especialmente, de percusión, como el pandero ${ }^{15}$, que lleva habitualmente

14 El denominado mito de la diosa lejana está documentado en la tumba de Sethy l y en él se narra como Hathor, encolerizada y transformada en Sekmet, la diosa leona, recorre Nubia provocando una auténtica matanza. Ra, horrorizado por la cólera de la diosa, envía una comitiva de dioses con la misión de apaciguarla mediante la música. En esta comitiva marchaba, entre otros, el propio Bes (Castel, E. 2001: 143). Es destacable la relación de este relato, donde los dioses logran sosegar a la divina leona mediante la música, con el mito de Orfeo de quien se decía que «sabía entonar cantos tan dulces, que las fieras lo seguían, las plantas y los árboles se inclinaban hacia él, y suavizaba el carácter de los hombres más ariscos [...] Con los acentos de su lira encantaba no sólo a los monstruos del Tártaro, sino incluso a los dioses infernales» (Grimal, P. 1981: 391-392).

15 «Los panderos y tambores desempeñaron una función ritual en el culto solar, el funerario, y posteriormente en el acompañamiento de música de danza». Existieron «varias formas de panderos entre las que cabe destacar los circulares de varios diámetros y los convexos, que aparecen representados en la iconografía del Imperio Nuevo tocados por mujeres» Pérez, R. 2001: 19. 
Beset en representaciones conjuntas en las que el dios suele aparecer como Bes guerrero $^{16}$.

Relacionado también con la función de Bes como protector del parto, ya que esta iconografía llegaría a confundirse con el Bes itifálico, es habitual otro elemento destacado en el determinativo de su nombre: la cola de león. Ésta aparece frecuentemente entre las piernas curvadas del dios y, cuando es representado de perfil, cayendo a sus espaldas, representaciones estas últimas habituales en el Reino Nuevo (Velázquez, F. «Consideraciones...»). En época ptolemaica, la preferencia por el antropomorfismo de los monarcas de origen griego, determinó la tendencia a la desaparición de este apéndice que era sustituido por una piel del animal colocada sobre la espalda, de modo que la cola continuaba apareciendo entre sus piernas, pero no ya como una característica híbrida del dios, sino como un atributo iconográfico. En ocasiones, esta vinculación entre el dios y el animal se complementaba con un medallón sobre el pecho de la divinidad que representaba una cabeza de león y hacía alusión metafórica a la estrecha relación entre ambos (Fig. 1).

La importancia simbólica de las pieles de los felinos en Egipto se detecta en el uso ritual que de ellas hicieron los sacerdotes. Éstos utilizaban la piel moteada del felino, bien fuera leopardo o guepardo, dispuesta sobre uno de sus hombros, nunca ceñida a la espalda casi en un abrazo simbólico, con las extremidades del animal cayendo sobre el pecho y los muslos, tal y como la lucía Bes. El modo en que este dios vestía la piel del león, a diferencia del modo tradicional relacionado con el sacerdocio, permitía que la cola del animal cayera entre sus piernas, entendiéndose así que no pertenecía a la figura antropomorfa sino que formaba parte de su atuendo. La utilización ritual de la piel de animales, desde época predinástica ${ }^{17}$, denota un significado profiláctico que no sólo transfería el poder del animal a su portador sino que también facilitaba el estado de trance que los sacerdotes precisaban para el desarrollo de algunos ritos ${ }^{18}$. Un texto procedente del papiro Jumilhac ejemplifica la relación de los sacerdotes con la piel del animal y justifica, desde el punto de vista ritual, la utilización de las pieles moteadas de los felinos:

«Seth [...] se transformó en una pantera [...] Después Anubis cortó la piel de Seth, le arrancó su piel y se puso la piel sobre él [...] Y el sacerdote Uab de este dios ha sido denominado Sem a causa de ello. Y él (Anubis) imprimió en él (Seth)

16 Se conservan dos relieves muy similares, ambos datados en la Baja Época, en el Allard Pierson Museum (APM 7947 y APM 7762), en los que aparece el dios Bes representado como guerrero, llevando un cuchillo en una mano y una serpiente en la otra, alegoría de su poder sobre los malos espíritus. En uno de ellos, procedente de Saqqara, aparecen dos formas circulares sobre el dios que pueden simbolizar panderos o bien escudos, haciendo referencia de nuevo al carácter guerrero del dios. En ambos, junto a Bes, aparece Beset, tocada en uno de ellos con una pluma, tañendo un pandero.

17 La importancia simbólica y mágica de la utilización de pieles de leopardo o guepardo está documentada en Egipto desde la Prehistoria, destacando una pintura de Hierakómpolis (Tumba 100. Cultura gerzeense, Nagada Ilc), donde ya se enfatizaba a una figura ataviada de este modo.

18 «Esto encajaría perfectamente en Egipto, sobre todo con el sacerdote "Sem", ya que una de sus labores era partir, en estado de trance, a la muerte del difunto, para buscar la "fuerza vital", el "alma" del difunto y hacerla retornar, así el fallecido podría participar de los ritos que se celebraban en los funerales». Castel, E. 1999: 223. 
su marca al fuego rojo, que quedó hasta el día de hoy. Hay una piel de pantera sobre el sacerdote Sem, por causa de ello hasta el día de hoy» ${ }^{19}$.

Se mitifica de este modo uno de los castigos sufridos por Seth después del asesinato de su hermano Osiris. Anubis le arranca la piel y la marca al fuego, lo que explicaría el moteado de la misma. Así pues, los sacerdotes vestirían la piel que, en origen, adornó al propio Anubis, hijo del asesinado Osiris y de su hermana Neftis. El sacerdote "sem" estuvo consagrado al culto de Ptah (Castel, E. 1998: 218), cuya relación con los enanos ha quedado patente; el vocablo $s m$, al margen de otros significados, puede hacer referencia a términos como "auxilio", "socorrer", "ayudar"20, lo que de nuevo describe el carácter profiláctico de la utilización de la piel del animal. Por otro lado, los sacerdotes $w^{c} b$, no estaban adscritos a ningún culto en especial, sino que componían una escala jerárquica en rituales de diferentes divinidades (Castel, E. 1998: 205). Su significado hace referencia a la purificación, generalmente mediante el agua y, ya en época romana, evolucionarían hacia la figura de los pastóforos dedicados al sacerdocio isiaco, a quienes Plutarco denominaría hieróforos o hieróstulos (PI. De Is. et Os. 3-4).

La tendencia general de época ptolemaica, imbuida del pensamiento griego, fue la antropomorfización de los dioses y, al igual que se representaba a Horus como un infante totalmente humanizado, se optaba por formas más humanas del dios Bes. Se mantendrían, por inercia iconográfica, las orejas de león, pero se obviaría la cola del animal, adoptando iconografías tendentes a la antropomorfización de la imagen del dios: bien fuera la colocación de una piel a la espalda, dotada de las cualidades del atuendo sacerdotal pero dispuesta a la manera hercúlea, bien fuera la forma itifálica del dios. Cuando se muestra a la divinidad con rasgos itifálicos, indudablemente, hay que relacionar la imagen con la protección del nacimiento y, más concretamente, con el momento de la concepción.

No es posible, en cualquier caso, establecer una evolución cronológica desde formas híbridas con cola de león en las primeras dinastías, hasta modelos itifálicos o con la piel del animal en época más tardía, ya que ambas iconografías convivieron en todo momento. Pueden citarse representaciones itifálicas del dios en Saqqara donde, incluso, se ha sugerido la existencia de cultos de fertilidad y prácticas relacionadas con la prostitución sagrada ${ }^{21}$. Asimismo, la figura de Aha,

19 Citado por Castel, E. 1999: 293. Según Vandier, J. 1962. Le Papyrus Jumilhac. París.

20 Sánchez, A. 2000: 369. Auxilio (Estela del camarero Montuuser del Metropolitan Museum de Nueva York [12.184), 11. Ägyptischen Lesestücken sum Gebrauch in akademischen Unterricht de Sethe, K. 79, 14/5), socorrer (Ptah-hotep 524. Les Maximes de Ptahhotep de Zaba, Z. Papiro Prisse 15, 12. Ägyptischen Lesestücken sum Gebrauch in akademischen Unterricht de Sethe, K. 72, 22), ayudar, sm $n$ (Readingbook de De Buck, A. RB 119, 8).

21 "Se conocen en Menfis lo que ha venido llamándose "las Habitaciones de Bes", lugares en los que se ha creído ver un culto a la fertilidad próximo a la prostitución (?), al sexo y los placeres libidinosos» (Castel, E. 2001: 102). "Son las denominadas "Habitaciones de Bes" encontradas por J. Quibell al este de la pirámide de Teti en Saqqara, donde aparecen relieves sobre los muros de las habitaciones 11 y 14 que representan a Bes itifálico teniendo en su mano izquierda una serpiente y un antílope, acompañado de una mujer desnuda» (Velázquez, F. «Consideraciones...»). 
habitualmente representado en los cuchillos mágicos del Reino Medio, era caracterizada también como itifálica. Esta divinidad estuvo indisolublemente relacionada con Bes por sus características leoninas, así como también por la frecuente aparición de serpientes en sus manos, aspecto que todavía mantendría Bes en la iconografía ptolemaica. Es habitual también su imagen en los pequeños biberones ${ }^{22}$ utilizados para la lactancia, como protector de los recién nacidos, así como su representación en compañía de Taweret $^{23}$. El origen de esta diosa nutricia que acompaña habitualmente tanto a Aha como a Bes puede ser «una entidad divina relacionada con el agua», función que «pudo asociarse a la rotura de la bolsa de agua en las mujeres gestantes» 24 . Finalmente, por otra parte, durante la Baja Epoca, Bes todavía conserva, en ciertas representaciones, el carácter híbrido que le otorgara la cola del león (Fig. 6).

La representación antropomórfica del dios Bes se asemeja a un híbrido por pormenores mucho más complejos que la simple unión del cuerpo humano con la cabeza del animal, o la inclusión de apéndices como las orejas o la cola, habituales también en otras divinidades. Es sintomático que, todavía en época ptolemaica, se destacaran en el rostro del dios las denominadas excreciones lacrimales (Velázquez, F. «Consideraciones...»). Este elemento es habitual en las imágenes del animal, y atiende a una profunda observación de la naturaleza acorde con el realismo del que los egipcios hicieron gala en escenas naturalistas; pero, sobre todo, denota la visión híbrida con que se concebía el rostro del dios, con el objetivo de modelar una expresión tan feroz que ahuyentara fácilmente a los malos espíritus.

Los atributos iconográficos de Bes en época ptolemaica, al margen de sus características leoninas y acondroplásicas, fueron múltiples y de muy compleja interpretación, ya que están íntimamente relacionados con una dilatada evolución iconológica que enriquecería el sentido profundo de la divinidad. La tradicional corona de plumas, cuya presencia hay que relacionar con los cultos de fertilidad ya que en divinidades masculinas hacen referencia a la virilidad (Castel, E. 1999: 331), muestra dos tipologías opuestas. Por una parte, esta corona alcanza un amplio desarrollo, siendo representada con todo detalle, mientras que, en otras imágenes del dios, el tocado se estiliza hasta quedar reducido únicamente a la base que sustentaba las plumas. Ambas iconografías perdurarían en época ptolemaica hasta el punto de que fueron transmitidas al mundo romano. Conviven de esta forma en los elementos de culto isiaco latino, tal y como puede observarse en la orla

22 Uno de ellos, conservado en el Metropolitan Museum of Art de Nueva York (MMA 1944. 44.4.4.), es reproducido por Velázquez, F. «Consideraciones...».

${ }_{23}$ Diosa de aspecto híbrido, representada como un hipopótamo hembra con garras de león y cola de cocodrilo, en la que destacan los pechos humanos caídos que hacen referencia al embarazo y la lactancia. La relación iconográfica e iconológica con Bes es evidente: ambas divinidades realizan labores de protección bajo un aspecto feroz - Taweret suele aparecer mostrando los dientes en actitud agresivadestinado a ahuyentar a los espíritus malignos; junto con Bes protagonizaba «músicas y danzas mágicas para celebrar el nacimiento del recién nacido". Aunque su iconografía habitual es la descrita, podía ser representada como una cerda (Castel, E. 2001: 427-429). También fue habitual su culto doméstico y en el ámbito cotidiano, como se deduce de algunos de los muebles procedentes de la tumba de Tuya y Yuya (Panel de cama. Museo de El Cairo, CG 51109).

24 Castel, E. 2001. P. 428. Según B. S. Lesko. 1999. The Great Goddesses of Egypt. Oklahoma. 
de la Tabla isiaca del Museo Egipcio de Turín ${ }^{25}$ donde, encubiertas entre elementos vegetales, se observan pequeñas cabezas de Bes muy estilizadas. La barba se confunde con la lengua expuesta del dios y apenas se aprecian diferentes mechones de la misma, casi a modo de tentáculos. Adaptándose al marco, en las orlas verticales, Bes porta su tocado completo, mientras que, en las horizontales, luce tan sólo la base de la corona. En el mundo grecorromano, esta base del tocado de Bes, cuando aparece aislada, puede recordar al calathos, la cesta de recolección de cereales que manifestaba la conexión de Serapis con la fertilidad agrícola y relacionaba a esta divinidad osiriaca con Plutón, que solía soportarlo sobre su cabeza. Cuando Serapis lucía este elemento simbolizaba la relación de los dioses alejandrinos con la fertilidad (Puech, H.C. 1985: 70). Plutón, sobrenombre ritual de Hades (Grimal, P. 1981: 220-221, 436), fue asimilado a Osiris por su condición de soberano del mundo subterráneo. La vinculación, en época ptolemaica y romana, de un elemento iconográfico propio de esta divinidad con Bes, estaría en relación con la fertilidad y con la concepción, sin embargo, existía una estrecha conexión del dios con el mundo del Más Allá.

En primer lugar, «era el guardián y vigilante de una de las Puertas del Mundo Subterráneo, la correspondiente al Horizonte Oriental» (Castel, E. 2001: 102). Pero, por otro lado, Bes, en el ámbito cotidiano, no sólo protegía los partos y todo lo relacionado con el matrimonio, sino que, dada la capacidad que se le atribuía para ahuyentar a los malos espíritus, preservaba también a los habitantes de la casa durante el sueño, momento que los egipcios, dada la indefensión del durmiente, consideraban proclive al ataque de demonios y entes dañinos. En el poblado de Deir el Medina, además de su presencia en pinturas murales, aparece también relacionado con el mundo funerario. Son característicos los denominados vasos plásticos que simulan la figura de Bes; estos recipientes han aparecido en las tumbas de los artesanos cercanas a la propia aldea, ubicados siempre muy cerca del difunto, con el objetivo de facilitar el eterno sueño del finado ${ }^{26}$. En este mismo sentido, es significativo que los lechos consagrados a la momificación estuvieran rematados con garras de león, decoración que, por otra parte, también era habitual en aquellos destinados al sueño. Así pues, podría relacionarse la figura de este animal y de su expresión divinizada - Bes- tanto con el descanso de los vivos, como protector del sueño y de la concepción, como con el reposo de los difuntos que, en su periplo por el mundo subterráneo, debían hacer frente a múltiples demonios y malos espíritus.

La vinculación de Bes al Más Allá se hace también patente en relación con El libro de los Dos Caminos, donde un grupo de demonios protectores consagrados a la salvaguardia de un lugar en que se atesora la esencia de la inmortalidad, son

${ }^{25}$ Constituye, con toda probabilidad, una mesa de altar, decorada con imágenes egiptizantes de corte alejandrino, entre las que pueden distinguirse representaciones de Bes. Un estudio más amplio en Leospo, E. 1978.

${ }_{26}$ Un buen ejemplo, datado en el Reino Nuevo, se reproduce en Velázquez, F. «Consideraciones...» (Tumba 1348 Deir el-Medina. Dasen, V. 1993. Dwarfs in Ancient Egypt and Greece. Oxford. P. 81. Fig. 6) 
denominados los Agachados. Estos demonios portan en sus manos serpientes, lo que los relaciona con Bes y con las representaciones de Aha en el Reino Medio; por otra parte, el calificativo de Agachados recuerda, sin duda, la curvatura de las piernas de Bes, así como su reducida estatura. Este sentido protector vinculado a la inmortalidad está también relacionado con Osiris y el poder fertilizante del dios, lo que de nuevo conectaría a estos demonios protectores con el propio Bes ${ }^{27}$. Existen también referencias a enanos protectores en diferentes secciones del Libro de los Muertos. El capítulo CLXIII precisaba de un ritual mágico para su recitación, lo que implicaba la inclusión de diversas imágenes; una de éstas «se semejará a la de un buitre, cubierta de plumas, y la imagen poseerá falo, un par de alas y las garras de un león», y se complementará con la efigie de "un enano, y detrás otro, cada uno emplumado, con una mano y un brazo en alto". Realizado este ritual «el difunto será divino en el submundo con los dioses; jamás, jamás será repelido; su carne y sus huesos serán como los del que nunca murió».

Similares cualidades mágicas a las de los lechos tuvieron los reposacabezas, que llegaron a ser considerados amuletos en sí mismos. Estos enseres, al igual que los tálamos, no sólo protegían a los vivos en su sueño, sino también a los difuntos en su eterno descanso, de ahí que se dotara de uno de ellos a las momias 0 , en su caso, de un amuleto que lo sustituyera ${ }^{28}$. Para potenciar la capacidad profiláctica de estos elementos, podían decorarse con divinidades, entre las que, por supuesto, se encontraba Bes, como en un ejemplar aparecido en la tumba de Tutankhamón (Museo de El Cairo. Carter 403D, J.d'E. 62023). Con este sentido de vigilancia nocturna es invocado también el «enano del cielo» en el siguiente texto, que describe a la divinidad con evidentes características acondroplásicas y la relaciona, además, con la custodia de los difuntos a través de su relación con Osiris:

¡Oh enano del cielo, el gran enano cuya cabeza es grande, cuya espalda es fuerte, cuyos muslos son cortos [...]! ¡Presta atención a NN nacido de NN! ¡Defiéndelo durante el día, vigílalo durante la noche, protégelo como protegiste a Osiris de Aquel-cuyo-nombre-es-odiado en el día de su entierro en Heliópolis! ${ }^{29}$

\footnotetext{
27 "Los "Agachados" parecen proteger la entrada de un lugar especialmente sagrado, que todos los sarcófagos esquematizan, pero sin dejar de señalar de alguna forma su elemento central. El mismo texto egipcio lo describe, y su importancia es tanta que la tinta utilizada es roja: "Este es el objeto que está en la oscuridad, y todo espíritu transfigurado que lo conoce vive entre los vivientes" [...] "Todo hombre que llegue a conocer esto, no puede morir, jamás" [...] La "Xtmt" aparece representada como una jarra cerrada y sellada que guarda la esencia misma de la divinidad, los humores que según la leyenda brotaron cuando Osiris fue despedazado por su hermano. En los TP - Textos de las Pirámides- se identifican con el agua del Nilo en su crecida, lo que significa fertilidad y abundancia, en definitiva un símbolo de vida como en este texto". Molinero, M.A. 1997.

28 «El reposacabezas guardaba cierta relación con el Sol. Igual que éste se levantaba cada mañana de entre dos colinas, el difunto (o el vivo) hacía lo propio cada mañana. El aspecto que presenta nos recuerda a la curvatura de las dos montañas de donde tradicionalmente emergía el astro solar». Como amuleto «tuvo varias funciones: sustituir al de tamaño natural, al que el difunto había empleado en vida, pero además orientar la cabeza del fallecido, levantarla para la resurrección y protegerla de cualquier eventualidad, ya que una de las mayores preocupaciones era perder la cabeza en el Mundo subterráneo. Castel, E. 1999: 339-340.

29 Borghouts, J.F. 1978: 90. P. British Museum 10042 [19] rt. 8, 9-9, 5. (H. Lange, Der magische Papyrus Harris, Copenhagen, 1927).
} 


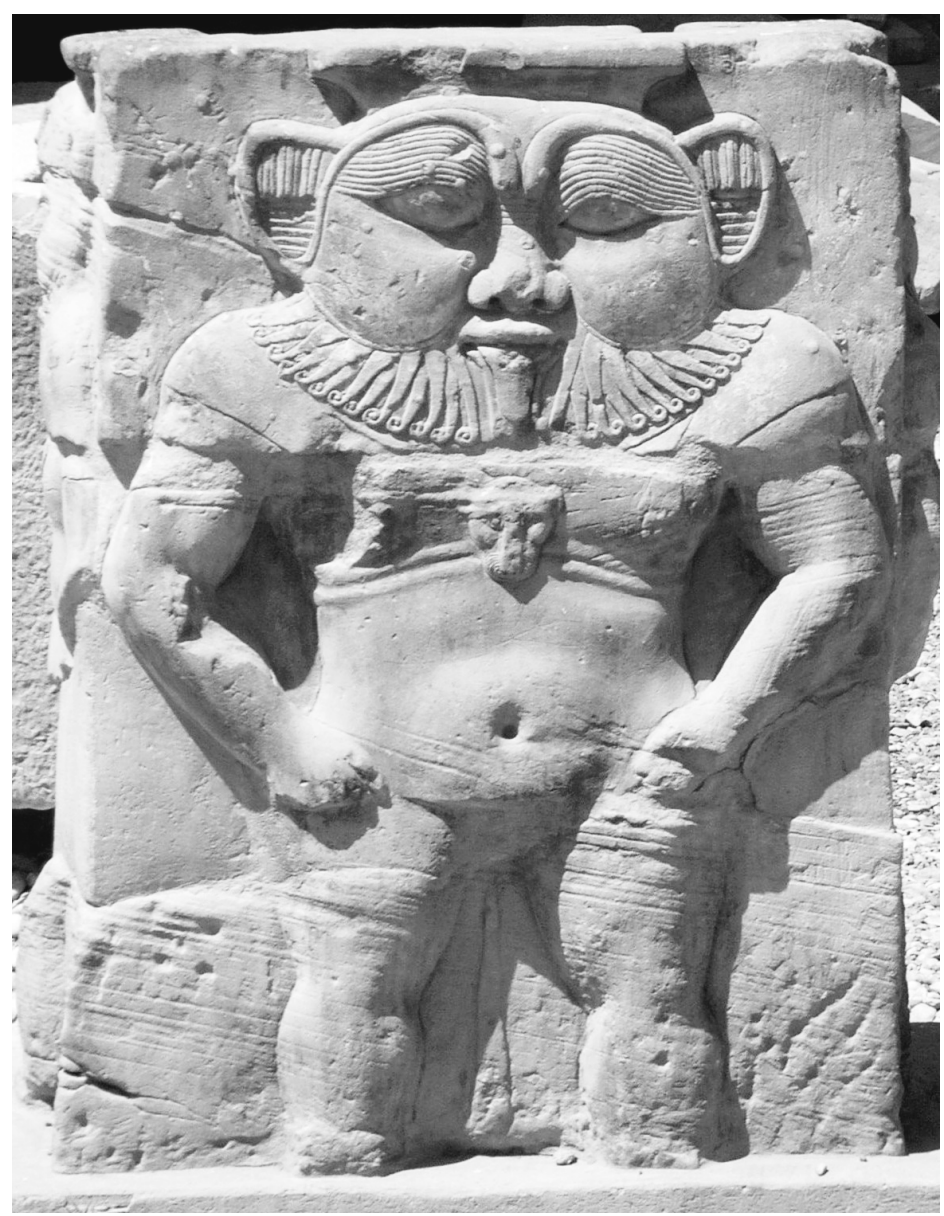

Fig. 1. Bes. Exterior del templo de Hathor en Denderah. Fotografía: A. Arroyo (2005).

Al margen de las implicaciones funerarias, los atributos de Bes evolucionaron iconográficamente de acuerdo con el proceso de antropomorfización que experimentó en época ptolemaica (Fig. 1). La melena ventral del león, más cercana a las características animales en sus primeras representaciones, se convirtió en la Baja Época en una poblada barba rematada por tirabuzones de corte barroco. Otro de los atributos habituales de Bes, especialmente del Bes guerrero, era el cuchillo que portaba en actitud feroz y en posición frontal para alejar a los malos espíritus. Los mangos de marfil de los cuchillos mágicos del Reino Medio, donde solía representarse a Aha, podrían relacionarse con esta iconografía. El cuchillo fue considerado un elemento ritual y el material utilizado, habitualmente colmillo de hipopótamo, ya denota una cualidad protectora al asimilar su portador la fuerza del animal. La tipología y el material empleados eran determinantes para el correcto desarrollo de rituales como, por ejemplo, la apertura de la boca y el costado de la 
momia, función para la que debía emplearse el denominado peseskhaf ${ }^{30}$. En el mismo sentido, el cuchillo utilizado para cortar el cordón umbilical debía ser de sílex (Castel, E. 1999: 141). Indudablemente, la trascendencia de su función dotaba a este instrumento de una capacidad mágico-protectora que podría ponerse en relación con el propio Bes. Así, aunque parece más acertado relacionar el cuchillo que lleva el Bes guerrero con su capacidad de ahuyentar a los malos espíritus que con la sección ritual del cordón umbilical, bien es cierto que el manejo litúrgico de este útil de sílex durante el parto perseguía idéntico objetivo, es decir, alejar y proteger al neonato de la acción de entes maléficos proclives a atacar al pequeño, indefenso tras la ruptura de su vínculo materno.

En la iconografía característica de Bes guerrero, el dios aparece siempre de frente, mientras que cuando se relaciona con la música y es representado danzando o tañendo instrumentos de percusión, se le suele presentar de perfil. El carácter feroz, agresivo, no sólo de su actitud —con el cuchillo en alto- sino también de su rostro, se acentuaba al mostrarlo de frente. Otra de las actitudes habituales de Bes en relación con esa mueca colérica encaminada a espantar a malos espíritus, era el gesto de sacar la lengua. En el mismo sentido, las serpientes que tanto Aha como Bes sujetan con sus manos, sugieren idéntica interpretación. Es cierto que existió una divinidad serpentiforme, Mehen, que defendía a Ra al frente de su barca en el periplo por el mundo subterráneo (Castel, E. 2001: 250.), donde se suponía que era atacado por gran cantidad de demonios y espíritus maléficos. No obstante, también Seth fue un dios guerrero que defendía a Ra a la cabeza de su nave solar ${ }^{31}$. Así pues, era habitual emplazar a dioses guerreros, malignos o particularmente violentos y poderosos a la cabeza de la barca de $\mathrm{Ra}$, como baluarte simbólico frente a los demonios del Más Allá. En el caso de la serpiente Mehen, puede adivinarse una actitud similar, ya que las serpientes eran consideradas animales maléficos; el Caos, que amenazaba el equilibrio de la creación, era representado por una de ellas, Apofis. Asimismo, en la escritura jeroglífica, a la que se suponía dotada de una especial capacidad creadora, se cuidaba de neutralizar el carácter maligno de estos animales, cercenando su cuerpo o hiriéndolos con cuchillos, para que la labor creadora del escriba o el artista no los dotara de vida (v. glosario). Otra divinidad serpentígera es el Harpócrates ptolemaico que, en las estelas mágicas, era representado no sólo con sierpes en las manos sino también sometiendo a otros animales maléficos, como escorpiones o cocodrilos. En este sentido, de hegemonía y victoria sobre los malos espíritus, es como debe interpretarse la iconografía de Bes-Aha.

Por último, atributo habitual de Bes fue el amuleto $s 3$ (v. glosario). Según lo interpreta Gardiner (Gardiner, A. 1988), se trata de una tienda de pastor, aunque otros investigadores piensan que puede tratarse de un abrigo o un flotador, en

30 Castel, E. 1999: 141. Sánchez, A. 2000: 184 (pš̌-kf; The Rock Tombs of Meir de Blackman, A.M., III, p. 28, n. 4).

31 «Entonces Set, grande en fuerza, hijo de Nut, dijo: «Yo, yo soy Set, igrande en fuerza dentro de la Enéada! Soy el único que mata al enemigo de Ra en la proa de la Barca Solar, y ningún otro dios puede hacerlo" (La Contienda de Horus y Seth. Kaster, J. 1970: 237-255) 
cualquier caso, un elemento vegetal con funciones protectoras acorde con su principal significado: «protección» (Castel, E. 1999: 343). Este elemento fue considerado como un amuleto y, con ese sentido, solían llevarlo tanto Taweret como el propio Bes, por ejemplo, en los paneles del lecho procedente de la tumba de Tuya y Yuya. El dios podía acompañarse también de otros amuletos, frecuentemente el ' $n h$, símbolo de la vida, como simples objetos mágicos; no obstante, en otro panel del citado lecho ${ }^{32}$, la sucesión de amuletos sugiere un auténtico texto en el que se califica al dios de Señor del Poder, la Protección y la Vida ( $n b$ w3s s3 ' $n h$ ), es decir, se le confiere la capacidad, el poder, de proteger la vida, de llevar a buen término el parto. En esta misma representación, el dios se muestra alado, imagen habitual durante la XVIII dinastía (Velázquez, F. «Consideraciones...»). El origen de esta iconografía, que algunos autores consideran oriental (Romano, J. F.: 1989), puede también proceder de Egipto, donde las efigies de dioses y, especialmente, de diosas aladas son habituales; en el caso de estas últimas, el significado de las alas estaba vinculado con fuerzas protectoras (Castel, E. 1999: 35). Las alas de Isis, que suele aparecer a espaldas de Osiris guarneciéndolo con ellas, aluden a su principal atribución mítica como eterna protectora del esposo. Por tanto, hay que relacionar las alas de Bes con esta acepción y con el amuleto s3 que suele llevar.

La contrapartida femenina de Bes, Beset, aparece representada en menor medida y, generalmente, en compañía del dios. Su iconografía es muy similar a la de Bes, hasta el punto de que, aunque no siempre se presenta como acondroplásica, la poblada melena que, en ocasiones, se une bajo su barbilla, sugiere un híbrido con cabeza de león y no de leona, como sería de esperar. El macho de esta especie estuvo relacionado en Egipto con el poder y la realeza ya desde época predinástica ${ }^{33}$, como personificación del faraón, ya que fue considerado un símbolo solar asimilando la melena ventral a los rayos del astro, y relacionando con el mismo los «fuertes rugidos que emite al amanecer y al anochecer» (Castel, E. 1999: 219). Esta identificación con el monarca, que se encarnaba en el animal, al igual que su personificación como Horus-halcón, se abandonó durante el proceso de antropomorfización helenístico, pero no así la relación del soberano con el animal ya que, en época ptolemaica, en el templo de Kom Ombo, el rey aparece acompañado del animal en idéntica actitud a la que mostrara en las paletas predinásticas, devorando enemigos, pero en este caso acompañándolo (Fig. 2), casi como una trasposición simbólica del faraón, nunca como una personificación en sentido estricto.

La leona, por su parte, representaba el carácter más cruel, más salvaje e incontrolado del animal, tal y como se mitifica en la leyenda de la diosa lejana (cfr. nota 14). Indudablemente, esta concepción estuvo vinculada al hecho de que quien caza es la hembra; no obstante, sus manifestaciones divinas también poseían un notable carácter maternal, ya que los cachorros permanecen con la madre un largo período de tiempo (Castel, E. 1999: 222). Por este motivo, estuvo rela-

32 Reproducidos ambos en Velázquez, F. «Consideraciones...» (Cairo, CG 51109. Davis, T. M. 1907. Tomb of louiya and Touiou, Finding of the Tomb. London. P. 37).

${ }_{33}$ Véase la Paleta del campo de batalla. Finales del Predinástico (ca. 3150 a.C.). Museo Británico (EA 20791). 


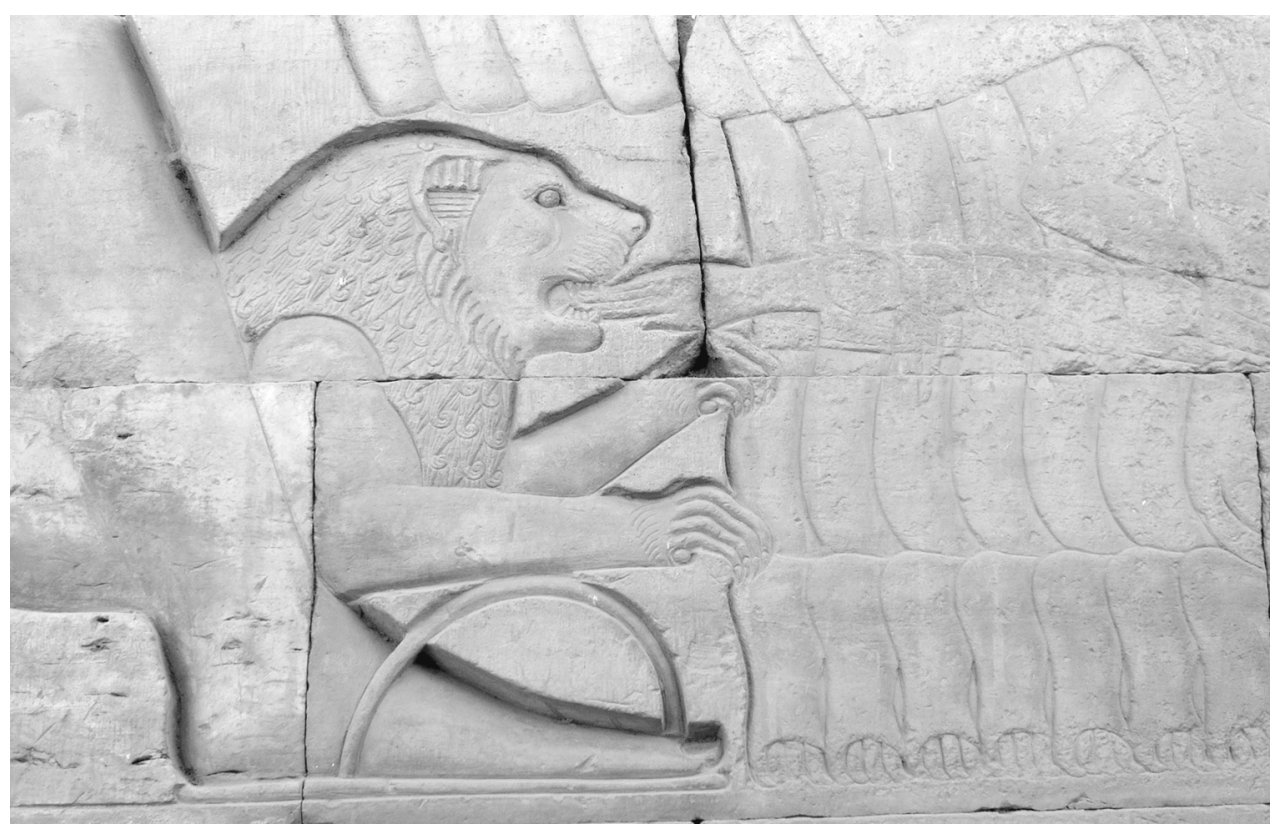

Fig. 2. Relieve del templo de Sobek y Haroeris en Kom Ombo. Fotografía: A. Arroyo (2005).

cionada con diosas nutricias o maternales como Bastet y Hathor; pero las imágenes de Beset no hacen alusión a diosas leonas como Sekmet o Mehyt, sino que su cabeza se asemeja más a la del propio Bes, un híbrido de león macho, destacándose únicamente los elementos propios del sexo femenino, los pechos y la vulva.

Al margen de la imagen estereotipada de Bes en el período ptolemaico, con rasgos leoninos y acondroplásicos y portando los diferentes atributos descritos, se desarrollaron otras iconografías peculiares del dios. En primer lugar, características del Tercer Período Intermedio son las terminales de fayenza en las que puede verse a Bes con un niño en brazos, así como aquéllas en las que el dios aparece sobre los hombros de otra figura (Velázquez, F. «Consideraciones...»). En cuanto a la primera tipología, portando un bebé, es indudable su relación con la protección de los nacimientos, pero el significado simbólico de la insólita iconografía del dios sobre los hombros de una persona, es de difícil interpretación. En época ptolemaica, fueron habituales las denominadas estelas o cipos de Horus-Harpócrates, en las que, si bien el dios no carga a Bes sobre sus hombros, éste aparece esbozado, simbolizado tan sólo por la cabeza, protegiendo al infante que pisotea y domina animales considerados malignos. La utilización únicamente del rostro del dios Bes de este modo durante las dinastías ptolemaicas, posibilitó la transmisión iconográfica al mundo romano de las máscaras de Bes (cfr. nota 25). Este tipo de estelas tenían la condición de objetos mágicos, ya que representaban la victoria de Harpócrates sobre las fuerzas del mal y se grababan en ellas textos destinados a curar la picadura de escorpiones, serpientes, etc.: 
«¡Aquí estoy, mi hijo Horus! [...] Hijo de gloriosa mujer, nada malo te pasará. ¡La semilla encarnada en ti es de quien creó aquello que existe! [...] Tú no morirás por el calor del veneno. [...]. Un gato te amamantó en la casa de Neith, una cerda y un enano protegieron tu cuerpo" 34 .

En este hechizo, en el que el afectado habla por boca de la diosa Isis para conjurar el veneno, se caracteriza a Horus como hijo de Osiris, tan poderoso que no puede ser vencido por el veneno, ya que ha sido criado para que crezca fuerte y sano, amamantado por un gato y protegido por un enano, Bes, y una cerda, que puede identificarse con Taweret (cfr. nota 23). La relación de Bes con la magia apotropaica también se detecta vinculada a su principal atribución divina, la protección en los partos. Al margen del carácter mágico de los cuchillos, existieron también hechizos destinados a facilitar el alumbramiento:

¡Oh dios enano, ven ya que te lo manda $\mathrm{Ra}$, el único que permanece de pie mientras Thot está sentado, sus pies sobre la tierra, abrazado por Nun, sus manos en el cielo! [...] Mira, Hathor colocará su mano en ella como un amuleto de salud ¡Yo soy Horus, quien la salva!

Las palabras serán dichas cuatro veces sobre un enano de arcilla, situado sobre una mujer que está dando a luz con sufrimiento ${ }^{35}$.

Cobra poder este conjuro, en el que se invoca al dios enano, gracias a la reiteración de las palabras, habitual en las prácticas de magia simpática, y a la presencia de un amuleto de terracota que representa a un enano. Es difícil comprender como un animal tan fiero como el león puede relacionarse con la protección de algo tan frágil como los recién nacidos, a pesar de los hábitos de cría de la leona, ya que hay que identificar a Bes con un león macho, por lo que no puede entenderse la defensa de los infantes en el sentido femenino de la especie. Más bien hay que suponer que se utiliza la figura del león como paradigma de la protección por su carácter extremadamente fiero. En este sentido, la escritura jeroglífica sugiere que la relación del león con la protección de los fetos o nonatos es muy temprana. Así pues, para designar estos dos conceptos existieron términos casi homófonos (v. glosario), rubricados por el determinativo genérico que claramente hacía referencia al elemento que designaba ${ }^{36}$. En el mismo sentido, otro de los términos empleados para designar al animal era, sino homófono, sí idéntico en cuanto a los símbolos fonéticos $(r-w)$, al utilizado para referirse a la acción de bailar ${ }^{37}$ (v. glosario); de

${ }^{34}$ Borghouts, J.F. 1978: 69-70. «Isis comes to the help of her son Horus». Estela Metternich [7] 7183 (Metropolitan Museum de Nueva York, MMA 50.85).

35 4261. Otro Hechizo Del Enano. Borghouts, J.F. 1978: 39-40. (P. Leiden I 348 [30] vs. 12, 2-6; J.F. Borghouts. The Magical Texts of Papyrus Leiden I 348, Leiden, 1971; OMRO 51: Oudheidkundige Mededelingen uit het Rijksmuseum van Oudheden te Leiden, Nieuwe Reeks, Leiden 1, 1920).

36 Sánchez, A. 2000: 197, m3i (Westcar 7,5. The Story of King Kheops and the Magicians Papiro Westcar-Berlin 3033 de Blackman, A.M.) y 198, m3y (Amarna VI, 27, 6. The Rock Tombs of El Amarna de Davies, N. de G.).

37 Castel, E. 1999: 296, rw (K. Sthe: Die altägyptichen Pyramidentexte. Leipzig 1908-22. Pyr.1351). Sánchez, A. 2000: 262, rwi (Urkunden des 18. Dynastie de Sethe, K. Continuado por Helck, W. Urk IV $259,16)$. 
nuevo, es el semagrama el que define el significado de la palabra. Así pues, también hubo de ser temprana la relación del león, en concreto de esta divinidad leontomorfa, con la música y la danza.

Adornada de esta compleja iconografía y dotada de tan confusa evolución iconológica, la efigie de Bes persistió en época ptolemaica y en los templos edificados bajo las dinastías macedonias. En estos santuarios, su representación se vinculó, sobre todo, a un pequeño edificio del que no carecería ninguno de los templos de época grecorromana: el mammisi. El término copto ma-m-misi, que acuñó Champollion en el siglo XIX para designar estas edificaciones, está estrechamente relacionado con el término egipcio $p r-m s w t$, casa del nacimiento ${ }^{38}$. Su etimología, por tanto, revela la función de estos edificios en los que sucedía el nacimiento del niño divino. Así pues, indudablemente, hay que situar su origen en las Salas del Nacimiento de la reina Hatshepshut en Deir el Bahari y de Amenhotep III en Luxor, donde se representó iconográficamente por vez primera la teogamia.

La monarquía egipcia se había basado desde sus inicios en la divinización del faraón, identificándole para ello como hijo de diversos dioses (Osiris, Ra, Amón). Sin embargo, las difíciles circunstancias en las que la reina Hatshepsut accedió al trono, obligaron a desarrollar todo un programa iconográfico que, dadas las dificultades que hubo de superar, tuvo que ser detalladamente estudiado. Al margen de asumir todos los símbolos de cariz masculino vinculados al poder faraónico, descartando otras filiaciones y dentro del contexto del culto solar de la dinastía XVIII, Hatshepshut se intituló hija de Amón e hizo al propio dios su padre y, por tanto, amante de su madre. El mismo procedimiento, con una iconografía prácticamente plagiada de Deir el Bahari y unos textos también muy similares, utilizaría Amenhotep III en el templo de Amón en Luxor. La iconografía desplegada en ambas salas del nacimiento es extremadamente detallada y desgrana todo el proceso de la concepción y el nacimiento del monarca divino, mediante símbolos de carácter metafórico que contrastan con el texto que los acompaña, mucho más explícito:

«Cuando Él (Amón-RA) se hubo transformado en la Majestad de su esposo, el Rey del Alto y del Bajo Egipto Men-Jeperu-Ra (Tutmosis IV), ique esté dotado de vida!, Él encontró (a Mut-em-Uia) reposando en la belleza de su palacio. Ella se despertó a causa del aroma que desprendía el dios. [...] Ella se alegró al ver sus bellezas y su amor recorrió todo su cuerpo. El palacio se inundó con el perfume del dios, todos sus aromas procedían (del país) del Punt. Mut-em-Uia dijo entonces en presencia del dios Amón-Ra: "¡Oh, cuán grande es tu poderío!, tu esencia se expande a través de todo mi cuerpo". Después de ello la Majestad de este dios hizo con ella todo cuanto deseó. Amón-Ra, Señor de los Tronos de las Dos Tierras dijo delante de la reina: "Amen-Hotep Heka Uaset (Amen-Hotep el Príncipe de Tebas), será el nombre de este niño que Yo he puesto en tu vientre [...] él ejercerá una realeza bienhechora sobre la totalidad de esta tierra [...] él gobernará las Dos Tierras como Ra, eternamente'[...]»39.

38 Castel, E. 1999: 92 (S. Aufrère, L’Univers Minéral s la Pensée Égyptienne. Vol l y Il. El Cairo 1991. P.249).

39 Citado por Martín, F.J. 1998: 48. (Urkunden des 18. Dynastie de Sethe, K. Helck, W. Urk IV, 1714, (6). 1715-1716). 
Amón se transforma a imagen del faraón con el objetivo de seducir a la reina, es decir, el dios usurpa la personalidad del marido tal y como se desarrollaría también la concepción de Hércules, ya que Zeus adoptó el aspecto de Anfitrión para que Alcmena accediera a sus propósitos (Grimal, P. 1981: 240). Curiosamente, es el perfume el que, en este caso, posibilita la identificación del dios por parte de la reina; en Deir el Bahari, muy cerca de la Sala del Nacimiento, en la denominada Sala del Punt, Hatshepshut se hizo eco de su exitosa campaña comercial al lejano país del Punt. Entre otros muchos productos importados de la zona, eran esenciales los perfumes que, en la sala del nacimiento, la reina hace propios de dioses, completando así un complejo programa iconográfico de propaganda del poder. Pero lo más trascendente es, sin duda, la frase final de este texto, donde por boca del propio Amón se anuncia la divinidad del heredero y, por lo tanto, se legitima plenamente su mandato. La proliferación de estos edificios en los templos de la Baja Época estuvo vinculada a la legitimación del poder de los monarcas ptolemaicos que, con ello, venían a asentar su autoridad en oposición a los invasores persas expulsados por Alejandro Magno. Las salas del nacimiento adosadas a los grandes templos cobraron entidad propia en las construcciones ptolemaicas, convertidas en edificios exentos $^{40}$ cuya importancia quedaba subrayada así dentro del recinto templario.

Desde el punto de vista iconográfico, en las teogonías de Deir el Bahari y Luxor se representaba el momento de la concepción mediante una bella metáfora en la que la pareja, sobre un lecho con garras de león, era elevada por encima del cielo por las diosas Selkit, protectora de los infantes y los difuntos, y Neith, demiurgo en la cosmogonía de Esna y madre del dios solar; transportados de este modo por encima de la bóveda celeste, Amón ofrecía a la reina el ' $n h$ h, la vida, para representar simbólicamente el instante de la concepción. El origen divino del futuro faraón se consolidaba con la imagen de Khum, el dios alfarero, también demiurgo en la cosmogonía tardía de Esna ${ }^{41}$, encargado de modelar el cuerpo del monarca. El ciclo finalizaba con una imagen destinada a un amplio tratamiento iconográfico posterior, la anunciación. En este caso, el encargado de confirmar a la reina que su futuro hijo procede de Amón, es Thot, dios de la sabiduría y patrón de los escribas que, más tarde, fue identificado con Hermes, el heraldo y mensajero de los dioses en la mitología griega. La iconografía habitual del mammisi ptolemaico recoge escenas de lactancia entre la diosa Hathor-Isis y el pequeño Horus, hijo de dios y futuro gobernante de las Dos Tierras. Por esta cuestión sucesoria, Isis luce el tocado hathórico de diosa nutricia combinado con el tocado isiaco original, el trono, que la identificaba como madre y protectora del monarca y subrayaba el carácter legitimador del edificio y de la iconografía empleada.

Los templos egipcios se concibieron como una casa de dios, como un microcosmos compuesto por columnas que simbolizaban la vegetación y sustentaban te-

\footnotetext{
40 Está documentado un mammisi adosado en el templo de Hathor en Deir-el-Medina, así como en el templo de Debod, actualmente en Madrid. Castel, E. 1999: 93.

${ }^{41}$ Las cosmogonías tardías de Esna y Elefantina, confieren la facultad de demiurgos a Neith, madre de todos los dioses, y a Khnum, el alfarero que modela con sus manos el huevo divino que contenía todas las formas de vida. Un estudio más amplio en Lopez, J. y Sanmartin, J. 1983: 69-76.
} 


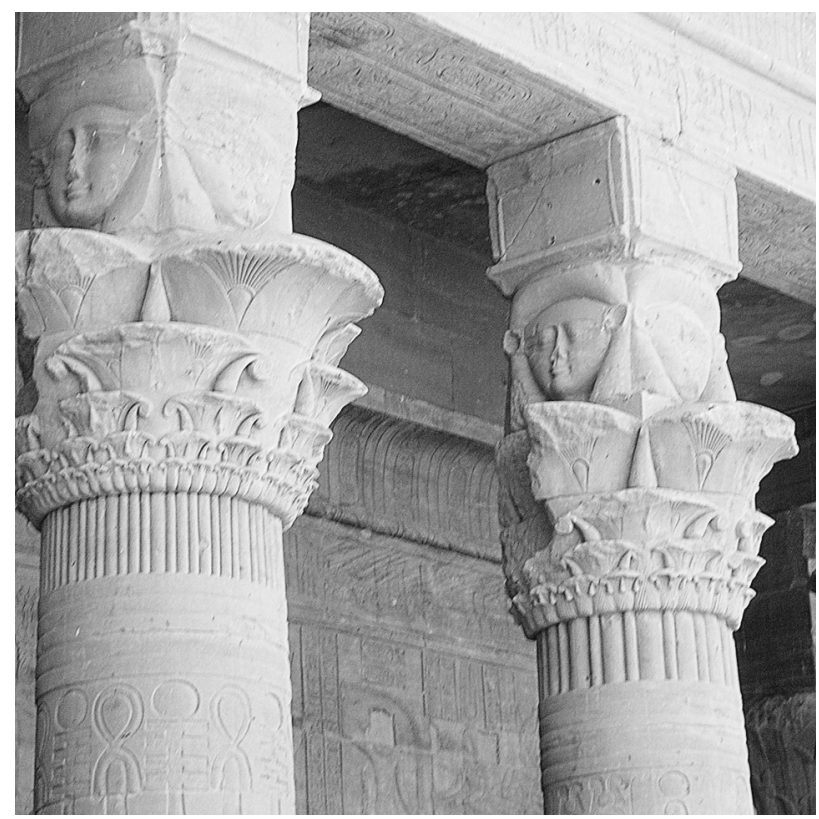

Fig. 3. Templo de Isis en Philae. Mammisi, capiteles hathóricos. Fotografía: A. Arroyo (2005).

chos orlados de estrellas, a modo de bóvedas celestes. Este programa iconográfico hacía referencia a las teorías cosmogónicas egipcias, que tuvieron un punto común: la vida surgía invariablemente en la colina emergida de las aguas del Caos, de donde nacería el niño divino. Esta colina primigenia, este oasis de la creación era el que los egipcios recreaban en sus templos. Pero este lugar sagrado debía ser concienzudamente protegido del Caos, motivo por el que el programa iconográfico desplegado en los templos tenía como objetivo la protección del espacio interior. El mammisi no sería una excepción en esta concepción arquitectónica y se vería salvaguardado de idéntica manera. Probablemente por influencia griega, estos templetes fueron perípteros, y las columnas que los rodeaban eran el primer elemento protector del lugar sagrado donde iba a producirse el nacimiento del dios.

El mammisi de Philae, se alza sobre columnas rematadas por airosos capiteles que constituyen una interpretación egipcia del orden corintio griego, elemento que sería común a los templos de época ptolemaica, sin embargo, el capitel se complementaba con la estilizada cabeza de Hathor (Fig. 3). Este esquema de representación en piedra de la testa antropomorfa de la diosa, con orejas de vaca y rematada por una naos, es paralela a la iconografía de los sistros compuestos ( $v$. glosario). El sistro, fetiche de Hathor que acabaría apropiándose Isis, formaba parte de los instrumentos idiófonos que, al igual que los de percusión que llevaban Bes y Beset, eran considerados «objetos mágicos con los que poder alejar las fuerzas del mal, y emitían sonidos que agradaban a las fuerzas del bien" (Castel, E. 1999: 360). Así pues, estos capiteles hathóricos, al margen de hacer referencia 
al aspecto nutricio y maternal de la diosa vaca, constituyen la primera defensa iconográfica del mammisi de Philae. El sentido simbólico del sonido de los sistros pervivía en época ptolemaica, no sólo en este sentido arquitectónico, ya que el propio Plutarco se refiere a ello en su De Iside et Osiride:

«El sistro indica también que todos los seres deben agitarse, no debiendo cesar nunca de ser movidos, pero que precisa asimismo despertarles y sacudirles haciéndoles salir de su estado de torpeza y marasmo. Los egipcios pretendían, en efecto, que Tifón - Seth- es apartado y rechazado por la agitación de los sistros, dándonos a entender que el principio corruptor traba y detiene el curso de la naturaleza, pero que la generación, por medio del movimiento, le desprende y restablece» (PI. De Is. et Os. 63).

Su presencia en el templo no es meramente decorativa, como no lo era casi nada en el entorno religioso del antiguo Egipto; en los templetes consagrados a la glorificación del nacimiento divino, la protección dedicada a los recién nacidos era especialmente importante. Así pues, los capiteles se decoraban con elementos apotropaicos, bien fuera el propio Bes, defensor de los neonatos por excelencia, o la diosa Hathor, vinculada tanto a su carácter nutricio como al poder del sistro para ahuyentar a los malos espíritus. Desde el punto de vista de la concepción, la representación iconográfica se plasma de modo aún más metafórico que en las salas del nacimiento de Hatshepsut y Amenhotep, de forma que en las columnas del mammisi de Philae se hace referencia a la unión entre Isis y Osiris a través de los fetiches de ambos, el pilar djed y el nudo tit (Fig. 4), también entendidos como

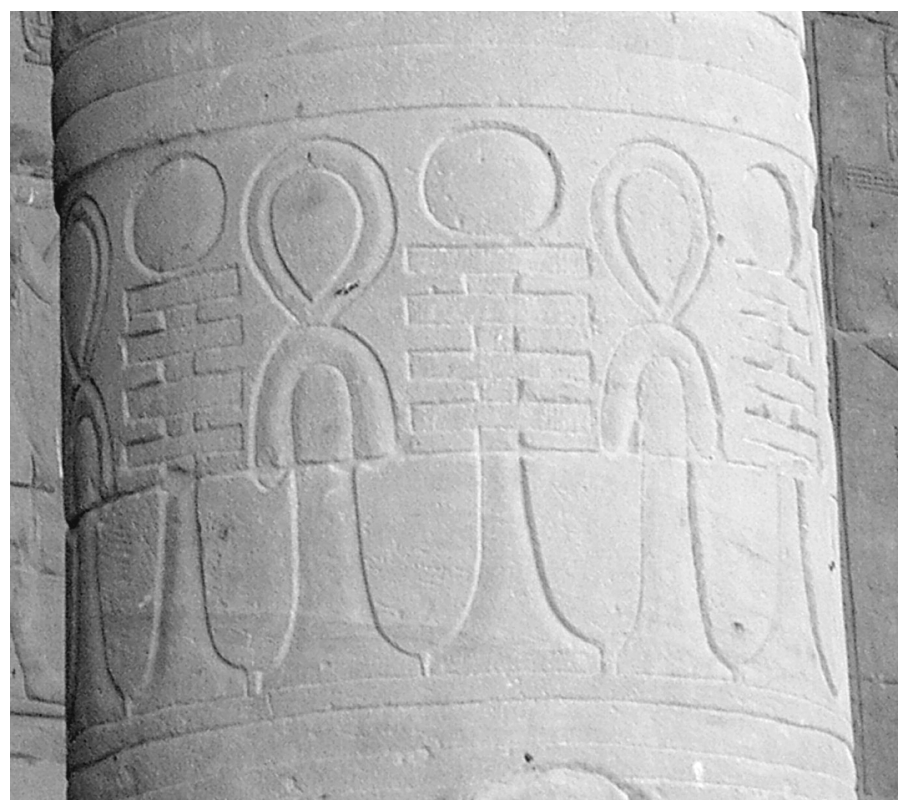

Fig. 4. Templo de Isis en Philae. Mammisi, detalle de la decoración de las columnas. Fotografía: A. Arroyo (2005). 


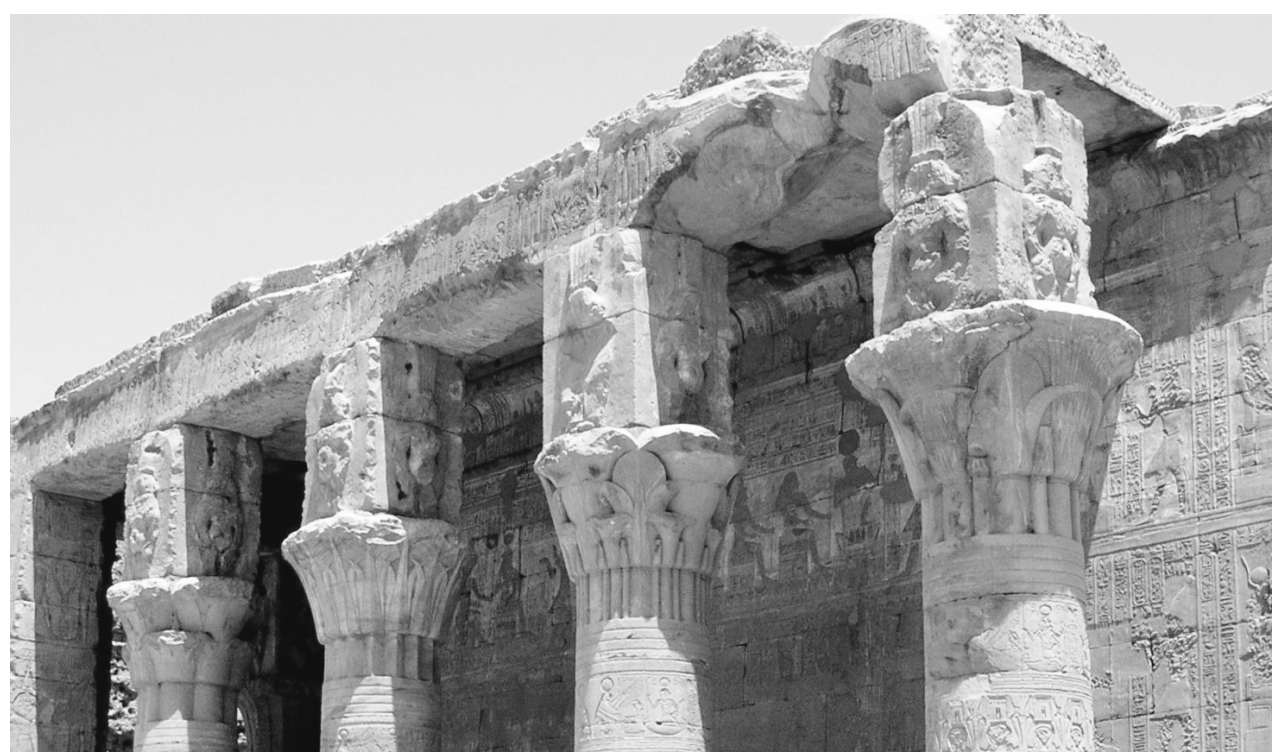

Fig. 5. Templo de Horus en Edfú. Mammisi, detalle de los capiteles. Fotografía: A. Arroyo (2005).

amuletos profilácticos. En el mammisi de Edfú los capiteles no están rematados con la tradicional cabeza hathórica sino por una figura de Bes; en este caso, la defensa que proporcionaran los capiteles hathóricos al asimilarse al poder simbólico del sistro, se acrecentaba, se podría decir incluso que se especializaba, con un elemento protector específico para lo que había de producirse en el interior del templo, el nacimiento, de forma que la divinidad elegida era aquélla especialmente poderosa de cara a la lucha contra los malos espíritus en el momento del parto (Fig. 5).

En el templo de la diosa Hathor es donde, en mayor medida, se desarrolla iconográficamente esta especial capacidad protectora de Bes. En primer lugar, en el friso del mammisi de Denderah, datado en época romana y heredero de conceptos ptolemaicos, aparece una imagen que subraya, de nuevo, el carácter apotropaico del programa iconográfico de estos templetes. Están representados Taweret y Bes flanqueando al niño solar que surge del loto en la cosmogonía hermopolitana ${ }^{42}$ (Fig. 6). Pero mientras el templo principal de Hathor se eleva sobre los bellos capiteles hathóricos del pórtico de acceso, el mammisi reitera la protección de Bes mediante una iconografía mucho más elaborada de la divinidad que la presente en

42 Dos son las versiones principales de esta cosmogonía: por un lado, aquélla que se refiere a la colina como la Isla de los Dos Cuchillos, donde la Ogdóada habría depositado el huevo del que habría de nacer el sol. Y por otro, aquélla que ubicaba el génesis cósmico en la denominada, a causa del nacimiento del astro, Isla del Incendio, en la cual había un estanque lleno de las aguas del Caos, donde habitaban los miembros de la Ogdóada y en el que flotaba un loto divino. Los machos de la Ogdóada habrían eyaculado sobre el loto, fecundándolo, y así, cuando a la mañana siguiente abrió sus pétalos, de su interior surgió el niño solar iluminando el mundo. Un estudio más amplio en Lopez, J. y Sanmartin, J. 1983: 55-60. 


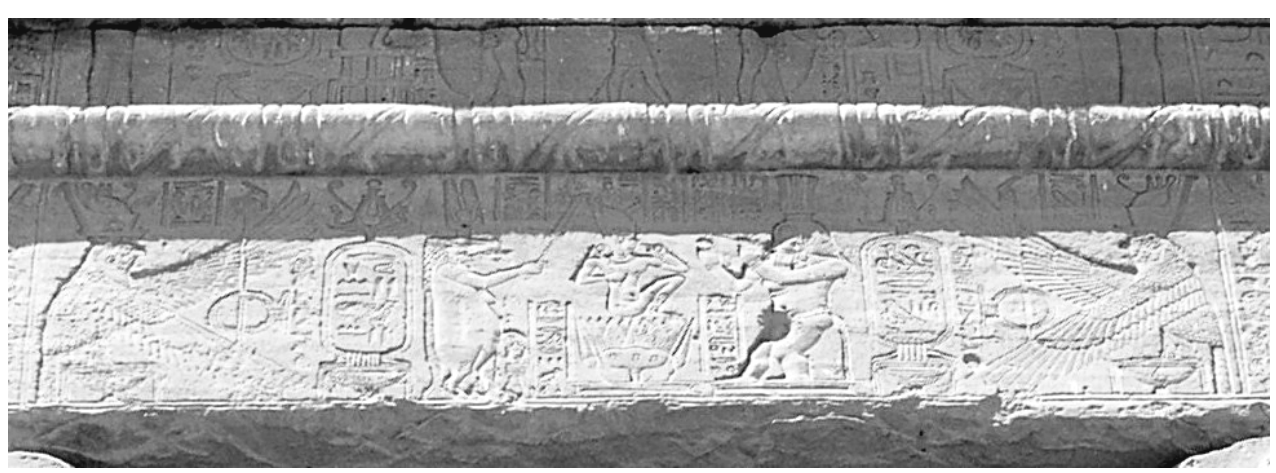

Fig. 6. Templo de Hathor en Denderah. Mammisi, detalle del friso. Fotografía: A. Arroyo (2005).

Edfú (Fig. 7). Destacan, al margen del rostro y las orejas leoninas, las dos líneas envolventes de orlas vegetales que sujeta con las manos $\mathrm{y}$, en este sentido, son varias las fuentes iconográficas que pueden citarse al respecto.

Cabe recordar, en primer lugar, las serpientes que someten tanto el dios Aha en los cuchillos mágicos como el Bes guerrero, con indudable carácter apotropaico y de demostración de poder frente a los malos espíritus. Por otra parte, el agua, elemento en el que se iniciaran todas las cosmogonías egipcias, fue un principio relacionado con la fecundación y la fertilidad (Castel, E. 1999: 26); además, se le atribuían ciertos poderes protectores y curativos. Taweret estaba relacionada con la rotura de aguas que precede al parto (cfr. nota 23) y, por su parte, sobre los cipos de Horus, coronados por la máscara de Bes, se derramaba agua que, pos-

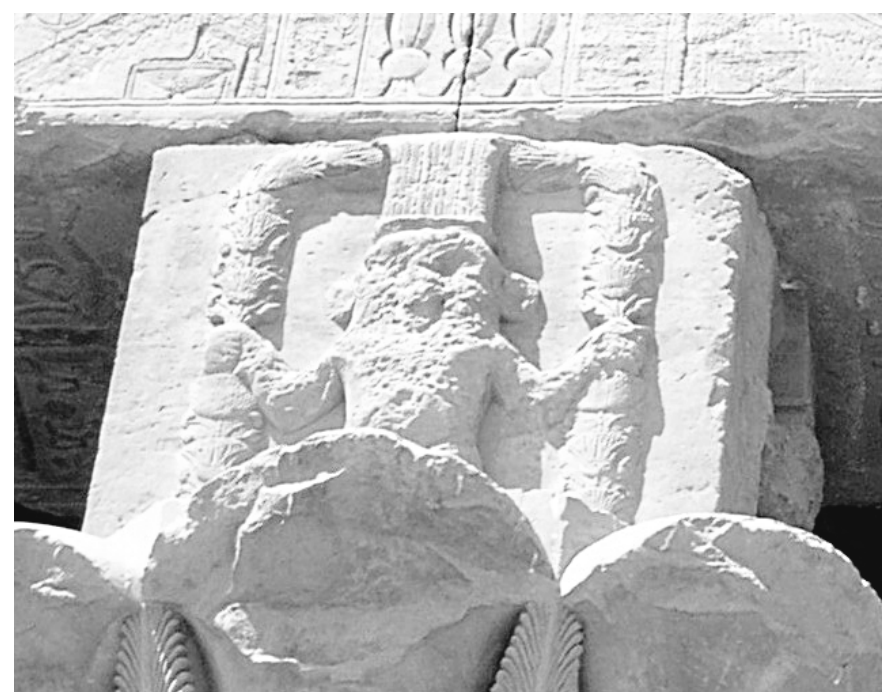

Fig. 7. Templo de Hathor en Denderah. Mammisi, capitel (detalle). Fotografía: A. Arroyo (2005). 
teriormente, debía beber el enfermo a modo de medicina ${ }^{43}$. Existió todo un repertorio iconográfico relacionado con esta función curativa, protectora y purificadora del agua que puede verse reflejado en la escritura jeroglífica ( $v$. glosario), en relación con términos vinculados a la purificación y el sacerdocio - $w^{c} b-$ (Sánchez, A. 2000: 139). En ocasiones, el agua, dado su poder fertilizador y vital era representada como símbolos ' $n h$; en el templo de Sethy I en Abydos, el monarca recibe las abluciones de Horus y Thot, que derraman sobre él la vida y el poder, simbolizando el agua con el ' $n h$ y el cetro $w 3 s$ (Castel. E. 2004: 67. Ilustr. 68). Por último, en el mammisi de Denderah, se produce, además, un complejo sincretismo entre Bes y el dios Heh. Éste podía ser representado de dos modos; por una parte, como miembro de la Ogdóada hermopolitana que formaba pareja con Hehet, su imagen tenía apariencia humana y cabeza de rana ${ }^{44}$. En este sentido, simbolizaba la infinitud de la creación y, al mismo tiempo, estaba relacionado también con las aguas. Pero existía otra representación iconográfica que obtuvo mayor difusión en el ámbito de lo cotidiano, al igual que Bes, apareciendo en muebles (Silla con el dios Heh. Museo de El Cairo, Carter 87, J.d'E 62029) u objetos de uso cosmético (Caja para un espejo. Museo de El Cairo, Carter 271C, J.d'E 62348). En estos casos, su apariencia era antropomorfa (v. glosario), arrodillado sobre el signo del oro, símbolo de eternidad e incorruptibilidad (Castel, E. 1999: 284-286), y sujetando con ambas manos, en disposición muy similar a la de Bes en el mammisi de Denderah, dos ramas de palmera; estos elementos vegetales se apoyaban sobre ranas que hacían referencia a su relación con la Ogdóada, y que simbolizaban «los millones de años de vida deseables para la existencia humana». Con esta forma fue venerado «en el Período Tardío como un dios del hogar» (Castel, E. 2001: 151-152) y, en este sentido, se convirtió, como Bes, en un patrón de lo cotidiano.

La iconografía de los capiteles del mammisi del templo de Hathor en Denderah recoge toda una compleja tradición iconológica del dios que, con la protección de los nacimientos como principal atribución, fue enriqueciéndose en relación con otras divinidades, como Aha, sometiendo a las serpientes, Taweret, haciendo referencia a la purificación por el agua, y el propio Heh, que consumaba el buen término del parto con un deseo de millones de años, en definitiva, con la anhelada aspiración de vida eterna.

Este enriquecimiento iconográfico e iconológico con el que culmina la figura de Bes en época ptolemaica le llevó a recibir un culto propio que, en época dinástica,

43 «Es indudable que el agua no tenía cualidades curativas, pero al menos servía para tranquilizar a un enfermo acosado por problemas respiratorios. [...] Otra posibilidad es que los egipcios supieran que bebiendo mucho agua se aumenta el volumen sanguíneo y la sangre se hace más fluida, consiguiendo que el veneno ataque de forma más débil». Castel, E. 1999: 108-109.

${ }_{44}$ En Hermópolis, el génesis del cosmos se atribuía a una Ogdóada, conjunto de cuatro parejas de genios, los Hehu, que, aunque en ocasiones fueron representados como monos cinocéfalos, habitualmente, los machos aparecían con cuerpo de hombre y cabeza de rana y las hembras con cuerpo de mujer y cabeza de serpiente. La Ogdóada, la componían Num y Naunet (personificaciones del Caos, el Agua Primordial), Heh y Hehet (conceptos de difícil determinación que pudieran representar bien el Extravío de las Aguas o bien el Infinito), Kek y Keket (las Tinieblas) y, por último, Amón y Amaunet (los Escondidos o lo Desconocido), aunque en algunos textos, éstos últimos son sustituidos por Niau y Niaunet, que personifican el Vacío. Un estudio más amplio en Lopez, J. y Sanmartin, J. 1983: 55-60. 
apenas había existido, apareciendo tan sólo en «templos dedicados a otros dioses donde se le rindió culto de forma secundaria» (Castel, E. 2001: 102). Así, cuando en el año 359 d.C. Constantino Il clausuró los ritos paganos, esta divinidad recibía culto propio en el templo de Sethy I en Abydos, hasta el punto de apropiarse del santuario, que entonces era conocido como Peribesion (Velázquez, F. «Consideraciones...»). Hasta este templo se organizaban peregrinaciones para acudir al oráculo que presidía el dios en la denominada sala de las barcas, donde, tras pasar la noche, el oráculo interpretaba los sueños. También la diosa Isis, cuyo culto pervivió en el Alto Egipto hasta la prohibición de Justiniano en el año 536 d.C., terminó por presidir un oráculo en el templo de Philae.

La evolución posterior de ambas divinidades, vinculadas en su periplo por otras culturas mediterráneas, acabaría eclipsada por el cristianismo que, en parte, asimiló muchos de los conceptos míticos egipcios; algunos, como la creación por el Verbo (cfr. nota 7), vinculados al pensamiento cosmológico, otros en relación con la teogamia. Se santificó el lugar del nacimiento del niño divino, y se desarrollaron iconográficamente imágenes como la anunciación o la Isis lactans y theotoka.

Pero, quizá por este mismo motivo, se inició un proceso destinado a la erradicación de los cultos paganos. No sólo se prohibió la liturgia en los templos egipcios sino que, además, se instauró el nuevo culto en estos lugares, anulando simbólicamente el poder de los antiguos dioses mediante el deterioro intencionado de las imágenes y santificando los espacios mediante la incisión de cruces y otros símbolos cristianos. En este sentido, la reacción inicial y especialmente rotunda contra los isiacos responde a dos causas esenciales: la persistencia de la liturgia isiaca la Inventio Osiridis se celebró todavía en el 417-y el «parecido cultual y teológico con el cristianismo que obligaba a puntualizaciones que marcasen las diferencias entre ambos rituales, más aún por cuanto el cristianismo reclamaba para sí el monopolio de la verdadera salvación frente a las religiones mistéricas» (Rubio, R. 1996: 66). El ejemplo de Fírmico Materno, con su obra «De errore profanarum religionum» ${ }^{45}$, es particularmente interesante si se tienen en cuenta las características que el autor atribuía al culto isiaco al objeto de desacreditarlo en Roma. La Biblia, en el contexto del Éxodo, recoge con toda claridad esta tendencia al enfrentamiento y la destrucción de los cultos egipcios:

«Y pegará fuego a los templos de los dioses de Egipto, y los abrasará, y los conducirá cautivos, y despiojará la tierra de Egipto como despioja el pastor su zamarra, y saldrá de allí en paz. Y romperá los obeliscos del templo del Sol en Egipto, y quemará los templos de los dioses de Egipto» (Jeremías 42, 12-13)

Imbuidos de esta tendencia a estigmatizar la religiosidad ancestral, dentro del territorio de Egipto, los textos coptos sometieron a Bes a idéntico proceso de descrédito al que sufriera la diosa Isis, siendo asimilado este dios a un demonio maléfico:

45 Un estudio más amplio en Montero, S. 1996. «La Isis de Fírmico Materno». En Rubio, R. (ed.). 1996: $65-75$. 
«Entró una vez en el templo que se encuentra al norte del convento un demonio llamado Bes. Con frecuencia salía fuera y golpeaba a los que pasaban por allí. Algunos de los que golpeó se quedaron tuertos, a otros se les paralizaron las manos, a otros las piernas, a otros se les torció el cuerpo y otros también se quedaron mudos. Mucha gente le había visto recorrer el templo y adoptar formas variadas, así que este demonio hizo mucho mal y Dios lo permitió a fin de poder mostrar Él sus prodigios » ${ }^{46}$.

Así pues, su evolución iconológica definitiva invertiría el significado de la iconografía del dios. Sus características híbridas con origen en cultos zoolátricos y en un proceso de antropomorfización intencionadamente interrumpido para subrayar un gesto agresivo, desafiante y feroz, incluso, la mueca de sacar la lengua, pasaron a ser habituales en las imágenes de demonios y seres destinados a aterrorizar, aún cuando, en su origen, fueron atributos iconográficos concebidos para proteger.

\section{BIBLIOGRAFÍA}

ANDREWS, C. 1994. Amulets of Ancient Egypt. Londres.

BENEDITE, M.G. 1893/95. Description et historie de L'ile de Philae. Memories publiés par les membres de la Missión Archéologique Française. París.

BORGHOUTS, J.F. 1978 Ancient Egyptian Magical Texts. Leiden.

CASTEL, E. 1998. Los sacerdotes en el Antiguo Egipto. Madrid.

CASTEL, E. 1999. Egipto. Signos y símbolos de lo sagrado. Madrid.

CASTEL, E. 2001. Gran Diccionario de Mitología Egipcia. Madrid.

CASTEL, E. 2004. Abidos. Templo de Sethy I. Barcelona.

DASEN, V. 1993. Dwarfs in Ancient Egypt and Greece. Oxford.

DAUMAS, F. 1958. Les Mammisis des temples Egyptiens. París

DAUMAS, F. 1959. Les Mammisis de Dendera. Le Caire.

FRASER, P.M. 1972. Ptolemaic Alexandria. Oxford.

GARDINER, A. 1988. Egyptian Grammar. Third edition, revised. Oxford.

GRENFELL, A. 1902. «The Iconography of Bes and Phoenician Bes-Hand scarabs». Proceedings of the Society of Biblical Archaeology, 24, p. 21 y ss.

GRIMAL, P. 1981. Diccionario de mitología griega y romana. Barcelona.

HERODOTO. 1986. Historia. Vol. 2. Libros III-IV. Madrid.

JEQUIER, G. 1946. Considérations sur le religions égyptiennes. Neuchâtel.

KASTER, J. 1970. The Literature and Mythology of Ancient Egypt. Londres.

KOENIG, Y. 1994. Magie et magiciens dans l'Égypte ancienne. París.

LARA, F. 1999. «Noticia de tres amuletos inéditos del dios Bes». BAEDE, n. ${ }^{\circ} 9$, pp. 149-156. Madrid.

LEOSPO, E. 1978. La Mensa Isiaca di Torino. Leiden.

LEXA, F. 1925. La magie dans l'Égypte Antique. Vol. II. París.

Libro de los Muertos. 1982. Traducción y prólogo de Juan A. Larraya. Barcelona.

LÓPEZ, J. y SANMARTIN, J. 1983. Mitología y Religión del Oriente Antiguo. Vol I. Egipto y Mesopotamia. Barcelona.

MARTíN, F.J. 1998. Amen-Hotep III. El esplendor de Egipto. Madrid.

MOLINERO, M.A. 1997. «La cartografía egipcia del Más Allá en los Libros Funerarios del Reino Medio». Realidad y Mito, cap. 9, pp. 173-201.

http://www.ull.es/proyectos/aguarel/cartografia.htm

46 Lexa, F. 1925. P.217-218. 
NÁCAR, E. y COLUNGA, A. 1983. Sagrada Biblia. Madrid.

ONIANS, J. 1979. Art and Thought in the Hellenistic Age. The Greek World View 350 a.C. 50 b.C. Londres.

PÉREZ, R. 2001. La música en la era de las Pirámides. Madrid.

PINCH, G. 1994. Magic in Ancient Egypt. London.

PLUTARCO. 1930. Isis y Osiris. Madrid.

PUECH, H.C. (ed.). 1985. Las Religiones en el Mundo Mediterráneo y en el Oriente Próximo. Formación de las Religiones Universales y de Salvación. Vol. I. Madrid.

RATIÉ, S. 1979. La reine Hatchepsout. Leiden.

ROMANO, J.F. 1980. «The origin of the Bes». Bulletin of the Egyptological Seminario, 2, p. 39 y ss.

ROMANO, J. F. 1989. The Bes-Image in Pharaonic Egypt. Doctoral dissertation, New York University.

RUBIO, R. (ed.). 1996. Isis. Nuevas Perspectivas. Madrid.

SÁNCHEZ, A. 2000. Diccionario Jeroglíficos Egipcios. Madrid.

SÁNCHEZ, A. 2004. Manual de Traducción de Jeroglíficos Egipcios. Madrid.

VELÁZQUEZ, F. «Consideraciones acerca de la evolución iconográfica del dios Bes». Web de la Asociación Española de Egiptología. http://www.egiptologia.com/aede/articulos/bes/bes.htm

VVAA. «La diabetes y otros trastornos endocrinos y metabólicos. La acondroplasia». MGC Health Systems. http://www.mcghealth.org/printer/internet/Greystone/speds/diabetes/achondro.html 


\section{Símbolos jeroglíficos y glosario de términos}

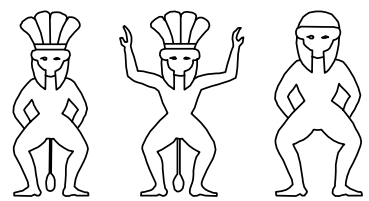

Signos C33, C33A y C34

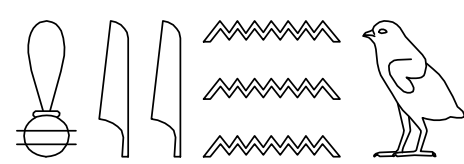

myw, enanos que realizan la danza funeraria

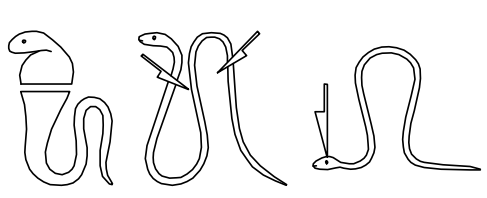

Signos 142-183-184-187

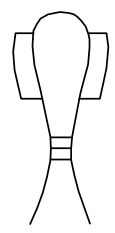

El amuleto $s 3$ (Signo V17)
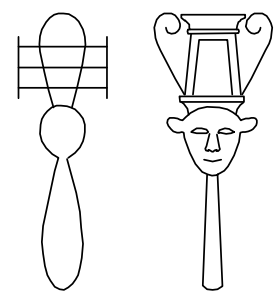

El sistro simple y el sistro hathórico

en la escritura jeroglífica (Signos Y18B-Y8)
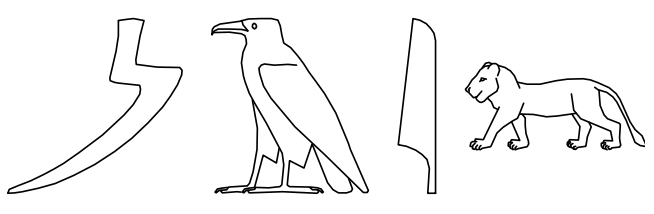

m3i, león

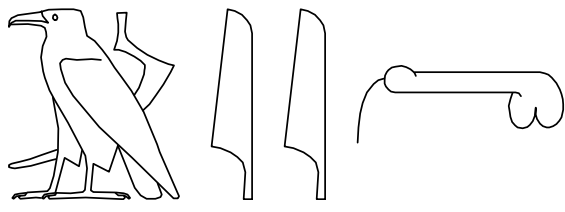

$m 3 y$, feto 


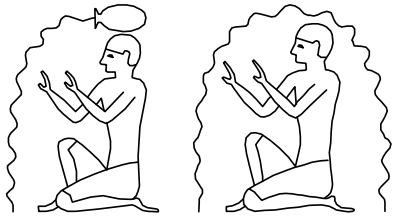

Signos A6, A6C y A133B

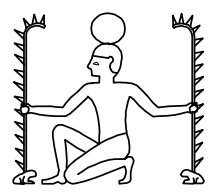

Heh (Signo C78C)
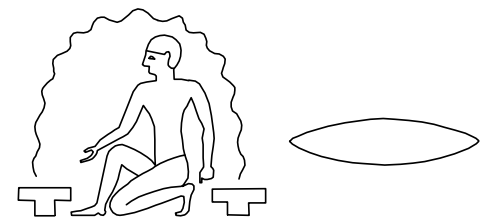

$r w$, león
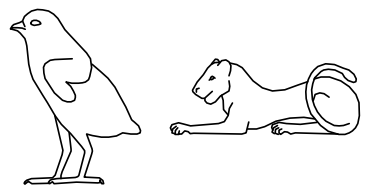
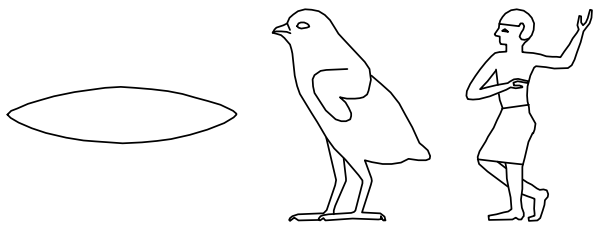

rwi, bailar 